\title{
Gold Diselenocarbamato Complexes
}

\author{
By J. G. M. van der Linden and W. P. M. NiJssen
}

With 1 Figure

Abstract. The preparation, u.v. and i.r. spectra and electrical conductivity of some gold diselenocarbamato complexes $\mathrm{Au}\left(\mathrm{et} \mathrm{t}_{2} \mathrm{dsc}\right),\left[\mathrm{Au}\left(\mathrm{et} \mathrm{d}_{2} \mathrm{dsc}_{2}\right] \mathrm{Br},\left[\mathrm{Au}\left(\mathrm{bu} \mathrm{d}_{2} \mathrm{dsc}\right)_{2}\right]\left[\mathrm{AuBr}_{2}\right]\right.$ and $\mathrm{Br}_{2} \mathrm{Au}\left(\mathrm{et}_{2} \mathrm{dsc}\right)$ are reported. [Au(et $\left.\mathrm{dsc}_{2}\right] \mathrm{Br}$ undergoes a reversible one-electron reduction with $\mathrm{E}_{1 / 2}=-0.43 \mathrm{~V}$ vs. $\mathrm{SCE}$, in contrast with the irreversible reduction observed for the analogous sulfur complex.

\section{Gold-diselenocarbamato-Komplexe}

Inhaltsübersicht. Darstellung, UV- und IR-Spektren und die elektrische Leitfähigkeit der Golddiselenocarbamato-Komplexe $\mathrm{Au}\left(\mathrm{et}_{2} \mathrm{dsc}\right),\left[\mathrm{Au}\left(\mathrm{et}_{2} \mathrm{dsc}\right)_{2}\right] \mathrm{Br},\left[\mathrm{Au}\left(\mathrm{bu}_{2} \mathrm{dsc}\right)_{2}\right]$ [AuBr$r_{2}$ ] und $\mathrm{Br}_{2} \mathrm{Au}\left(\mathrm{et}_{2} \mathrm{dsc}\right)$ werden beschrieben. Die Reduktion durch Utbertragung eines Elektrons des $\left[\mathrm{Au}\left(\mathrm{et}_{2} \mathrm{dsc}\right)_{2}\right] \mathrm{Br}$ bei $\mathrm{E}_{1 / 2}=-0,43 \mathrm{~V}$ (gegen SCE) ist reversibel, im Gegensatz zu der irreversiblen Reduktion des analogen Schwefelkomplexes.

The existence of gold(HI)diselenocarbamate has recently been detected with esr techniques ${ }^{1}$ ). However, no pure sample of a gold diselenocarbamato complex could be obtained by these investigators.

We succeeded to prepare in low yields crystalline samples of $\mathrm{Au}\left(\mathrm{et}_{\mathbf{2}} \mathrm{dsc}\right)$, $\left[\mathrm{Au}\left[\mathrm{et}_{2} \mathrm{dsc}\right)_{2}\right] \mathrm{Br}$ and $\mathrm{Br}_{2} \mathrm{Au}\left(\mathrm{et}_{2} \mathrm{dsc}\right) . \quad\left(\mathrm{R}_{2} \mathrm{dsc}=\mathrm{N}, \mathrm{N}\right.$-di-alkyldiselenocarbamate; $R_{2}$ dtc $=N, N$-di-alkyldithiocarbamate). The gold(I) complex was obtained from the reaction of dibromoaurate(I)-containing solutions with $\mathrm{Zn}\left(\mathrm{et}_{2} \mathrm{dsc}\right)_{2}$ and the rapid extraction and purification of the formed precipitate. The gold(I) complex is unstable in solution and disproportionates easily. Thus, $\left[\mathrm{Au}\left(\mathrm{et}_{2} \mathrm{dsc}\right)_{2}\right] \mathrm{Br}$ was prepared from the reaction of $\mathrm{AuBr}_{2}^{-}$with $\mathrm{Zn}\left(\mathrm{et}_{2} \mathrm{dsc}\right)_{2}$, when the reaction mixture was left standing overnight. From excess $\mathrm{AuBr}_{2}^{-}$with $\mathrm{Zn}\left(\mathrm{bu}_{2} \mathrm{dsc}\right)_{2}$ the $\left[\mathrm{Au}\left(\mathrm{bu}_{2} \mathrm{dsc}\right)_{2}\right]\left[\mathrm{AuBr}_{2}\right]$ complex was prepared. Treatment of $\left[\mathrm{Au}\left(\mathrm{et}_{2} \mathrm{dsc}\right)_{2}\right] \mathrm{Br}$ with bromine resulted in the formation of $\mathrm{Br}_{2} \mathrm{Au}\left(\mathrm{et} \mathrm{t}_{2} \mathrm{dsc}\right)$.

1) R. Krrmse, B. Lorenz, W. WINdsoh and E. Hoyer, Z. anorg. allg. Chem. 384, 160 (1971). 
The ultra violet spectrum of $\mathrm{Au}\left(\mathrm{et}_{2} \mathrm{dsc}\right)$ in DMF is nearly equal to that found for $\left[\mathrm{Au}\left(\mathrm{bu}_{2} \mathrm{dtc}\right)\right]_{2}{ }^{2}$ ) (Fig. 1). For the $\left[\mathrm{Au}\left(\mathrm{et}_{2} \mathrm{dsc}\right)_{2}\right] \mathrm{Br}$ complex in dichloromethane solution the absorption maxima are shifted to a lower frequency as compared with the $\left[\mathrm{Au}\left(\mathrm{bu}_{2} \mathrm{dtc}\right)_{2}\right] \mathrm{Br}$ complex $\left.{ }^{3}\right)$. The intense band found at $34.3 \mathrm{kK}(\varepsilon \simeq 46.000)$ may be compared with the band at

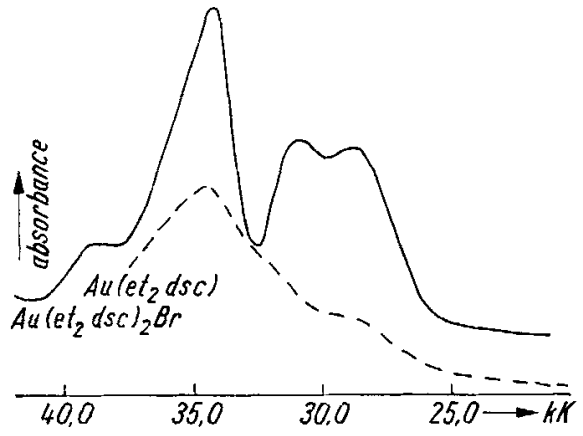

Fig.1. Ultraviolet spectra of gold diselenocarbamato complexes

$36.1 \mathrm{kK}$ found for the sulfur analog. The absorption maxima found at $30.9 \mathrm{kK}(\varepsilon \simeq 24.000)$ and $28.9 \mathrm{kK}(\varepsilon \simeq 23.000)$ for the selenocomplex may be compared with the intense band at $31.6 \mathrm{kK}$ found for $\left[\mathrm{Au}\left(\mathrm{bu}_{2} \mathrm{dtc}\right)_{2}\right] \mathrm{Br}$ (Fig. 1).

The results of the recorded infrared spectra are given in Table 1 . The $\mathrm{C}-\mathrm{N}$ stretching frequency for the gold(III)diselenocarbamates is found approximately $10 \mathrm{~cm}^{-1}$ lower as compared with the sulfur complexes. The $v\left(\mathrm{Au}-\mathrm{Se}\right.$ ) is calculated at $264 \mathrm{~cm}^{-1}$ (found: $253 \mathrm{~cm}^{-1}$ and $259 \mathrm{~cm}^{-1}$ ) from the gold-sulfur stretching frequency at $378 \mathrm{~cm}^{-1}$ and with only the mass effect taken in consideration.

Table 1

Infrared Absorption Bands of Gold diselenocarbamato Complexes (cm-1)

\begin{tabular}{|c|c|c|c|}
\hline Complex & $\nu(\mathrm{C}-\mathrm{N})$ & $\begin{array}{c}v(\mathrm{Au}-\mathrm{S}) \\
\text { or } v(\mathrm{Au}-\mathrm{Se})\end{array}$ & $v(\mathrm{Au}-\mathrm{Br})$ \\
\hline$\left[\mathrm{Au}\left(\mathrm{et} \mathrm{t}_{2} \mathrm{dtc}\right)\right]_{2}$ & 1493 & & \\
\hline$A u\left(e t_{2} d s c\right)$ & 1494 & & \\
\hline$\left[\mathrm{Au}\left(\mathrm{et}_{2} \mathrm{dtc}\right)_{2}\right] \mathrm{Br}$ & 1545 & 378 & \\
\hline$\left[\mathrm{Au}\left(\mathrm{e} \mathrm{t}_{\mathrm{g}} \mathrm{dsc}\right)\right] \mathrm{Br}$ & 1533 & 253 & \\
\hline$\left[\mathrm{Au}\left(\mathrm{bu}_{\mathbf{2}} \mathrm{dtc}\right)_{\mathrm{a}}\right]\left[\mathrm{AuBr} \mathrm{s}_{\mathbf{z}}\right]$ & 1550 & 380 & 255 \\
\hline$\left[\mathrm{Au}\left(\mathrm{bu}_{2} \mathrm{dsc}\right)_{2}\right]\left[\mathrm{AuBr} \mathrm{r}_{\mathrm{z}}\right]$ & 1539 & 250 & 250 \\
\hline $\mathrm{Br}_{2} \mathrm{Au}\left(\mathrm{et}_{3} \mathrm{dtc}\right)$ & 1573 & 378 & 243,216 \\
\hline $\mathrm{Br}_{2} \mathrm{Au}\left(e \mathrm{t}_{2} \mathrm{dsc}\right)$ & 1562 & 259 & 247,222 \\
\hline
\end{tabular}

2) H. J. A. BlaAUw, Ph. D. Thesis, Nijmegen 1965.

3) P. T. Beurstens, J. A. Cras and J. G. M. van Der Linden, Inorg. Chem. [Washington] 9, $475(\mathbf{1 9 7 0 )}$. 
Conductivity measurements of $\left[\mathrm{Au}\left(\mathrm{et}_{2} \mathrm{dsc}\right)_{2}\right] \mathrm{Br}$ in nitrobenzene in the concentration range $(2-9) \cdot 10^{-4}$ molar revealed this complex to be a 1:1 electrolyte with $A_{0}=33.3 \mathrm{~cm}^{2} \mathrm{ohm}^{-1}$ mole $^{-1}$. With this value and the single ion conductivity of the bromide ion (21.9) the single ion conductivity $\lambda_{0}\left[\mathrm{Au}\left(\mathrm{et}_{2} \mathrm{dsc}\right)_{2}^{+}\right]=11.4$ could be calculated. This value is about the same as was found for $\mathrm{Au}\left(\mathrm{bu}_{2} \mathrm{dtc}\right)_{2}^{+}$and $\mathrm{Cu}\left(\mathrm{bu}_{2} \mathrm{dtc}\right)_{2}^{+}$being $\left.9.1^{4}\right)$ and $\left.9.2^{5}\right)$, respectively.

Like the sulfur containing complexes the $\mathrm{Au}\left(\mathrm{et}_{2} \mathrm{dsc}_{2}^{+}\right.$ion could be reduced at $-0.43 \mathrm{~V}$ vs $\mathrm{SCE}$ in $\mathrm{CH}_{2} \mathrm{Cl}_{2}$ solution using a rotating platinum electrode. The redox reaction was reversible $\left(\mathrm{E}_{3 / 4}-\mathrm{E}_{1 / 4}=63 \mathrm{mV}\right)$ in contrast with the irreversible reduction found at $-0.26 \mathrm{~V}$ for the analogous $\left[\mathrm{Au}\left(\mathrm{et}_{2} \mathrm{dtc}\right)_{2}\right] \mathrm{Br}$ compound $\left.{ }^{6}\right)$.

In view of the similar behaviour of the $\mathrm{Au}\left(\mathrm{et}_{2} \mathrm{dsc}_{2}^{+}\right.$and $\mathrm{Au}\left(\mathrm{et} \mathrm{d}_{2} \mathrm{dsc}\right)_{2}^{+}$ complexes it is reasonable to assume that they have the same plannar geometry.

\section{Experim ental}

Physical measurements. Infrared spectra were recorded with a Perkin Elmer 257 and a Hitachi EPI-L spectrophotometer, using the KBr disc technique. Ultraviolet spectra were recorded with a Unicam SP 800 spectrophotometer. Voltametric ${ }^{7}$ ) and electrical conductivity measurements ${ }^{4}$ ) were carried out as described.

Preparations. $\left.\left.\left.\mathrm{Au}\left(\mathrm{et}_{2} \mathrm{dtc}\right)^{8}\right), \quad\left[\mathrm{Au}\left(\mathrm{et}_{2} \mathrm{dtc}\right)_{2}\right] \mathrm{Br}{ }^{4}\right), \quad\left[\mathrm{Au}\left(\mathrm{bu}_{2} \mathrm{dtc}\right)_{2}\right]\left[\mathrm{AuBr}_{2}\right]^{8}\right), \quad \mathrm{Br}_{2} \mathrm{Au}$ $\left.\left(\text { et }_{2} d t c\right)^{10}\right)$ and $\mathrm{Zn}\left(\mathrm{et}_{2} \mathrm{dsc}\right)_{2}{ }^{11}$ ) were prepared as described.

$\mathrm{Au}\left(\mathrm{et}_{2} \mathrm{dsc}\right)$. A saturated aqueous salt solution of $0.30 \mathrm{~g} \mathrm{KAuBr}{ }_{4}$ was reduced at $-5^{\circ} \mathrm{C}$ with an equivalent amount of sodium sulphite as described ${ }^{8}$ ). This solution was immediately added to $\left.0.15 \mathrm{~g} \mathrm{Zn(et}{ }_{2} \mathrm{dsc}\right)_{2}$ dissolved in $10 \mathrm{ml}$ of DMF. A red precipitate was obtained which was extracted with three $100 \mathrm{ml}$ portions of chloroform. The yellow chloroform solution was filtered and to the filtrate diethyl ether was added until the first cloudiness. After cooling at $0^{\circ} \mathrm{C}$ for three hours the formed red precipitate was filtered and thoroughly washed with methanol to remove the gold(III)diselenocarbamates. In this way $0.05 \mathrm{~g}$ of a crystalline product was obtained $\mathrm{mp} .174^{\circ} \mathrm{C}$ dec.

Anal. found:

C 14.5; $\mathrm{H} 2.4 ; \quad \mathrm{N} 3.1 ; \quad$ Au $45.9 ;$

cale. for $\mathrm{C}_{5} \mathrm{H}_{10} \mathrm{NSe}_{2} \mathrm{Au}$ : C 13.68; H 2.30; N 3.19; Au 44.86 .

4) J. G. M. van der Linden, Recueil Trav, chim. Pays-Bas 90, 1027 (1971).

5) A. W. GAI, personal communication.

6) J. G. M. VAN DER LINDEN, J. inorg. nuclear Chem. 34, 1645 (1972).

7) J. G. M. VAN DER LINDEN and H. G. J. vaN DE Rokr, Inorg. Chim. Acta 5, 254 (1971).

8) S. Äkenstrom, Ark. Kemi 14, 387 (1959).

9) P. T. Beurskens, H. J. A. BlaAuw, J. A. Cras and J. J. Steggerda, Inorg. Chem. [Washington] 7, 805 (1968).

10) P. T. Beurskens, J. A. Cras and J. J. Steggerda, Inorg. Chem. [Washington] 7, 810 (1968).

11) D. Barnard and D. T. Woodbridge, J. chem. Soc. [London] 1961, 2922. 
[Au(et dsc $_{2}$ ] Br. A solution of $0.61 \mathrm{~g} \mathrm{KAuBr}_{4}$ in $750 \mathrm{ml}$ of a methanol-water mixture (2:1) saturated with potassium bromide was reduced as described above. This solution was added to $0.30 \mathrm{~g} \mathrm{Zn}\left(\mathrm{et}_{2} \mathrm{dsc}\right)_{2}$ dissolved in $15 \mathrm{ml}$ of chloroform. The solution turned red and was stirred for five hours. After standing overnight a dark brown precipitate was formed, which was removed by filtration. The filtrate was extracted twice with $100 \mathrm{ml}$ of chloroform. The chloroform was removed in vacuo and the orange red product was recrystallized twice from ethanol giving $0.05 \mathrm{~g}$ orange red needles $\mathrm{mp} .265^{\circ} \mathrm{C}$ dec. Another $0.05 \mathrm{~g}$ crystalline product was obtained by adding diethyl ether to the ethanol filtrates.

Anal. found: $\quad$ C 16.0; $\mathrm{H} \mathrm{2.5;} \mathrm{N} \mathrm{3.9;} \mathrm{Br} \mathrm{10.4;} \mathrm{Au} 26.3$;

calc. for $\mathrm{C}_{20} \mathrm{H}_{20} \mathrm{~N}_{2} \mathrm{Se}_{4} \mathrm{AuBr}$ : $\mathrm{C} 15.78 ; \mathrm{H} 2.65 ; \mathrm{N} \mathrm{3.68;} \mathrm{Br} 10.50 ; \mathrm{Au} 25.89$.

[Au(buldsc $)_{2}$ ] [ $\mathbf{A u B r}_{2}$ ]. 1.1 $\mathrm{g} \mathrm{KAuBr}_{4}$ in $700 \mathrm{ml}$ of a saturated salt solution was reduced as described above. This solution was immediately added to $0.32 \mathrm{~g} \mathrm{Zn}$ (bu $\left.\mathrm{bu}_{2} \mathrm{dsc}\right)_{2}$ dissolved in $25 \mathrm{ml}$ of DMF. The resulted solution was extracted with $\mathrm{CH}_{2} \mathrm{Cl}_{2}$ during which extraction an appreciable amount of the complex decomposed in gold and selenium. A red product result after filtration and evaporation of the solvent. This product was washed with methanol and recrystallized from dichloromethane and diethyl ether. $0.05 \mathrm{~g}$ of a yellow crystalline product was obtained mp. $149-152^{\circ} \mathrm{C}$.

Anal. found: $\quad$ C 19.1; H 3.2; N 2.5; Au 35.2;

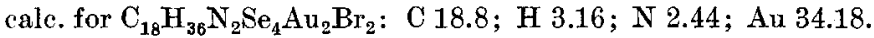

$\mathrm{Br}_{2} \mathrm{Au}$ (et $\mathrm{t}_{2}$ dsc.). To a solution of $0.0 \leq \mathrm{g}$ of $\left[\mathrm{Au}\left(\mathrm{et}_{2} \mathrm{dsc}\right)_{2}\right] \mathrm{Br}$ in $10 \mathrm{ml}$ of $\mathrm{CH}_{2} \mathrm{Cl}_{2}$ was added $0.01 \mathrm{~g} \mathrm{Br}_{2}$ in $10 \mathrm{ml}$ of the same solvent. Diethyl ether was added till the first cloudiness appeared. On cooling $0.02 \mathrm{~g}$ brown needles were obtained $\mathrm{mp} .286^{\circ} \mathrm{Cdec}$. This product showed no conductivity in nitrobenzene solutions. The recrystallization of $0.01 \mathrm{~g}$ of this product in acetonitrile yielded $0.005 \mathrm{~g}$ red needles.

$\begin{array}{lll}\text { Anal. found: } & \mathrm{C} 10.9 ; \mathrm{H} 2.1 ; \mathrm{N} 2.7 \\ \text { calc. for } \mathrm{C}_{5} \mathrm{H}_{10} \mathrm{NSe}_{2} \mathrm{AuBr}_{2} ; \mathrm{C} 10.03 ; \mathrm{H} 1.68 ; \mathrm{N} 2.34 .\end{array}$

Acknowledgement. The authors wish to thank Professor J. J. STEGgerda for his interest in this work and Mr. T. M. J. Bollex and Mr. H. L. CoeneN for the preparation of $\mathrm{Zn}\left(\mathrm{et} \mathrm{dsc}_{2}\right)_{2}$ and $\mathrm{Zn}\left(\mathrm{bu}_{2} \mathrm{dsc}\right)_{2}$.

Nijmegen, Department of Inorganic Chemistry, University of Nijmegen, The Netherlands.

Bei der Redaktion eingegangen am 19. Januar 1972.

Anschr. d. Verf.: J. G. M. vaN Der Linden and W. P. M. NiJssen

Department of Inorganic Chemistry, Toernooiveld

Nijmegen (The Netherlands)

Chefredakteur: Professor Dr. Dr, h. c. Gūnther Rienäcker, DDR-1199 Berlin-Adlershof, Rudower Chaussee 5. Anzeigen Inland: DEWAG-Werbung Leipzig, DDR-701 Leipzig, Brühl 34-40, Ruf 79740. Ausland: Interwerbung GmbH, DDR-104 Berlin, Tucholskystr. 40, Ruf 425196. Zur Zeit gilt Anzeigenpreisliste 7. Verlag Johann Ambrosius Barth, DDR-701 Leipzig, Salomonstraße 18 b, Ruf 25245 . Veröfentlicht unter der Lizenz-Nr. 1388 des Presseamtes beim Vorsitzenden des Ministerrates der DDR

Druck: VEB Druckhaus Röthen, DDR-437 Köthen (IV/5/1) L 121/72

Printed in the German Democratic Republic 